\title{
HIDUP MARADEKA DALAM TATA RUANG RUMAH BUGIS
}

\author{
Hartawan Madeali \\ Departemen Arsitektur Fakultas Teknik Universitas Hasanuddin \\ Jalan Poros Malino KM. 6 Bontomarannu Gowa \\ *Email: hartawanmadeali@yahoo.com
}

\begin{abstract}
Maradeka life is the highest idea of Bugis ethnic in South Sulawesi Province. Life and maradeka terminology are a unity which is found by exploring Bugis script called lontaraq.The research topic is learning from Bugis in planning and design space. The main objective of this study was to reveal the basic consideration of Bugis ethnic in space design which is applied in they traditional house. The research method is historical interpretation and logical argumentaion. Historical interpretation to reveal the meaning of maradeka in script. Logical argumentation to reveal local knowledge in space problem solving for human better life. The script which used to explain maradeka derived from lontaraq Meong Mpalo and lontaraq Attoriolonge Ri Wajo. The study results that Bugis house space design for maradeka life. The application of maradeka life is suitable to vertical space arrangement in Bugis house. The highest space in Bugis house function as food stuff storage as life warranty. The lowest space function as the support of daily life. The human space placed in the middle of life warranty and support of daily life. This space composition suitable to used as basic consideration in macro planning too. Good planning should be prepared space for food stuff, space for living, and space for supporting life. This spaces should be interconnected and proportional to regard for humanity.
\end{abstract}

Keywords: Maradeka, Life, Bugis House.

\section{PENDAHULUAN}

Provinsi Sulawesi Selatan dihuni oleh 4 etnis yaitu, Bugis, Makassar, Mandar, dan Toraja. Etnis Bugis adalah etnis yang mendominasi jumlah dan luas kawasan domisili. Etnis ini memiliki ciri khas berupa rumah tinggal berbentuk panggung dan catatan peninggalan budaya yang disebut lontaraq. Lontaraq yang paling populer adalah Lontaraq Galigo yang diakui oleh UNESCO (Jakarta Post 28 April 2012) sebagai memory of the word (MOW). Lontaraq lainnya masih dapat ditemui dalam dokumen arsip nasional dan dalam bentuk warisan yang dipegang secara pribadi oleh pemiliknya. Penelitian ini menggunakan 2 lontaraq sebagai sumber utama yaitu, Lontaraq Pangajaqna Meong Mpaloe (MPL) dan Lontaraq Attoriolongnge Ri Wajo (ATRW). Kedua lontaraq ini pada dasarnya memuat pesan yang sama namun dibalut dalam keterangan yang berbeda. ATRW menerangkan kondisi tatanan sosial, ekonomi, dan pemerintahan di negeri pertama di dunia yang menganut tatanan pemerintahan maradeka. MPL memuat keterangan tentang falsafah hidup dan kehidupan mulia yang didambakan oleh masyarakat Bugis.

Kehidupan dan masyarakat dimasa lalu merupakan fenomena yang sarat dengan makna dan selalu menarik sebagai objek penelitian termasuk fenomena yang terjadi dalam kehidupan masyarakat Bugis dalam hal permukiman dan rumah tinggal. Uraian berikut menjabarkan fenomena.

Naskah Galigo melukiskan permukiman Bugis didirikan di dataran rendah, dataran dekat muara sungai atau dekat danau. Permukiman berubah berpindah kepuncak bukit pada saat kekacauan politik terjadi. Kronik Bugis menyatakan bahwa permukiman Bugis terdiri dari kelompok kecil dan berjauhan disana-sini, atau tersebar disekitar lahan mereka. Situasi lingkungan permukiman disebutkan bahwa kadang-kadang suatu permukiman akan tumbuh pesat dalam waktu singkat dan juga dapat ditinggalkan dalam waktu singkat pula atau 
perpindahan penduduk ke suatu daerah baru (Pelras, 2006).

Broke Pada tahun 1840 James Brooke berkunjung ke salah satu kerajaan Wajo kuno di Tosora dan menggambarkannya sebagai kota besar yang berantakan. Daerah lain yang disebutkan adalah Lagosi yang juga terletak di Kabupaten Wajo dengan kondisi yang sama, pada tahun tersebut diperkirakan berpenduduk 10.000 jiwa (Pelras, 2006).

Kondisi perkampungan masyarakat Bugis seperti yang terbentuk saat survei 2011, masih dapat dianggap baru karena perkampungan tersebut terbentuk pada tahun 1965 dengan dikeluarkannya Surat Keputusan Gubernur Sulawesi Selatan tanggal 20 Desember 1965, No. 450/XII/1965 (Mattulada, 1995).

Rumah Bugis dibangun di atas tiang yang terdiri dari 3 (tiga) susun yaitu, rakkeang, ale bola dan awa bola. Rakkeang untuk menyimpan padi dan bahan makanan lain. Di samping itu di bagian ini juga digunakan sebagai ruang penyimpanan pusaka keluarga. Ale bola atau batabbola digunakan untuk tempat tinggal manusia yang digunakan untuk menerima tamu, ruang tidur, ruang makan dan dapur. Awa Bola atau awa sao digunakan untuk menyimpan binatang ternak atau peralatan dan perlengkapan kerja. Peralatan dan perlengkapan kerja, umumnya untuk kegiatan pertanian dan nelayan. Pembagian ruang rumah menjadi 3 susun secara vertikal sebagaimana disebutkan di atas juga didasarkan atas pandangan kosmologis orang Bugis yang menganggap bahwa alam semesta ini terdiri dari 3 tingkatan yaitu botting llangiq, ale kawa dan uriq liu (Mardanas, Abu, Maria, 1985). Alam atas untuk para dewa, Alam tengah untuk manusia dan alam bawah untuk binatang dan kehidupan bawah permukaan tanah dan air.

Keterangan tentang fenomena menarik kehidupan masyarakat Bugis dimasa lalu yang berkaitan dengan rumah tinggal dan permukimannya menjadi inspirasi untuk menelusuri lebih jauh dalam kaitannya dengan kepercayaan dan prinsip hidup.

Penelitan ini adalah penelitian lanjutan kami dari penelitian sebelumnya yang menemukan analogi prinsip hidup maradeka dengan tatanan ruang rumah Bugis menurut tinjauan hierarki ketegasan batasan ruang. Hierarki ketegasan batasan ruang rumah Bugis secara vertikal analog dengan hierarki kebebasan dalam prinsip hidup maradeka. Analoginya mengikuti pengaturan ruang bawah rumah Bugis dirancang untuk kebebasan yang besar, ruang tengah untuk kebebasan yang dapat dibatasi, dan ruang atas untuk penguasa dan pengendali kebebasan (Hartawan, Suhendro, Pradipto, Kusumawanto, 2015).

Hasil penelitian sebagaimana disebutkan diatas ternyata telah mengungkap kesesuaian hidup maradeka dengan kebebasan bergerak secara fisik dan lahiriah. Penelitian akan menelusuri lebih jauh dalam hal-hal yang berkaitan dengan prinsip hidup yang paling mendasar. Pembahasan dan kajian paper ini akan menelusuri dan mengungkapkan dasar pertimbangan yang dilakukan oleh masyarakat Bugis jaman dahulu untuk merancang tatanan ruang arsitektur di bangunan rumah tinggalnya, sebagai tujuan penelitian.

Tema arsitektur dalam literatur maupun penelitian yang umum ditemukan terkait bentuk dan ruang arsitektur rumah di Sulawesi Selatan secara umum menyamakan antara etnis Bugis dan etnis Makassar. Kedua etnis ini memang memiliki beberapa persamaan tetapi perbedaan diantara keduanya dalah hal bangunan rumah tidak dapat disamakan karena memang berbeda. Hal ini perlu dipertegas karena etnis di kawasan semenanjung selatan Pulau Sulawesi memiliki karekteristik tersendiri. Fenomena perbedaan ini tentunya menjadi bukti kekayaan budaya bangsa. Dalam penelitian ini fokusnya adalah Bugis.

\section{METODE PENELITIAN}

Metode yang digunakan dalam penelitian ini adalah interpretive historical research dan logical argumentation. Keadaan suatu fenomena dapat ditelusuri kembali mengenai berbagi hal yang terjadi atau berkaitan dengan objek yang diteliti melalui metode penelitian interpretive historical research. Penelitian yang dapat mengungkapkan kerangka sistem secara luas dan juga mengungkapkan cara-cara yang terkandung dalam sistem dan keterkaitannya dengan keberlanjutan sistem menjadi keunggunalan metode logical interpretation (Groat, Wang, 2002). Interpretasi sejarah untuk mengungkapkan makna kata maradeka yang terdapat dalam lontaraq. Argumentasi logika untuk mengungkapkan penerapan prinsip hidup maradeka dalam perencanaan dan perancangan tata ruang di rumah Bugis.

Interpretasi sejarah melalui wawancara dan penelusuran lontaraq (MPL dan ATRW). 
Penelusuran ini akan mengungkapkan makna hidup dan maradeka. Hasil penelusuran tersebut dilengkapi dengan wawancara mendalam kepada tokoh masyarakat Bugis yang masih memiliki kepedulian dan pemahaman akan makna kata tersebut. Dengan demikian tautan antara keterangan lontaraq dengan penjelasan tambahan sebagai upaya agar dapat memperkuat kebenaran nilai kajian.

Wawancara mendalam diperlukan karena mengingat kebiasaan masyarakat Bugis dalam melestarikan ilmunya menggunakan 2 cara yaitu cara tertulis dan cara penyampaian langsung. Pelestarian dengan cara tulis dimuat dalam catatan tersendiri yang lasim disebut lontaraq. Pelestarian dengan cara penyampaian langsung dilakukan dengan cara budaya tutur. Perihal yang disampaikan dengan budaya tutur dilakukan terhadap konten yang besifat pribadi yang mana ilmu tersebut hanya dapat dipahami oleh orang tertentu dalam keturunannya menurut darah.

Argumentasi logika dilakukan dengan melihat analogi dan kajian yang sesuai antara prinsip hidup maradeka dengan tatanan ruang yang terjadi di rumah Bugis.

Objek penelitian adalah bangunan rumah Bugis yang diperkirakan telah berumur ratusan tahun atau dibangun sebelum jaman kemerdekaan NKRI. Batasan sampel ini digunakan untuk menjamin keaslian bangunan rumah Bugis. Unit analisisnya adalah tatanan ruang dalam secara vertikal.

Hasil kajian interpretasi sejarah dan argumentasi logika ditautkan dengan fenomena tata ruang vertikal di rumah Bugis dijadikan sebagai dasar penyimpulan penelitian.

\section{HASIL DAN PEMBAHASAN}

Hasil dan pembahasan memuat tentang uraian pengertian hidup dan maradeka dilanjutkan dengan uraian keterkaitannya dengan bangunan rumah dan diakhiri dengan tinjauan penggunaan prinsip hidup maradeka dalam tata ruang makro.

\section{Pengertian Hidup Menurut Pandangan Masyarakat Bugis}

Hidup dalam bahasa Bugis disebut tuwo, dan merupakan hal yang sangat mendasar. Manusia dapat bertahan hidup bilamana mereka makan nasi yang bersumber dari padi. Dalam padi inilah terkandung sesuatu yang bernilai tuwo. Padi dalam pandangan Bugis adalah wakil Dewi Padi (Sangiang Serriq $=$ SGSR). Dewi Padi adalah titisan Tuhan Esa (Puang SSeuwwae) yang bertugas menjamin kelangsungan hidup manusia di dunia. Manusia yang telah makan akan dapat melangsungkan hidupnya yang ditandai oleh keluar-masuk dan atau turun-naiknya napas.

Fenomena makan dan nafas adalah hal yang penting bagi masyarakat Bugis. Seorang anak Bugis akan menggunakan kondisi napasnya sebagai bahan pelajaran ketika bangun tidur untuk dijadikan sebagai persiapan atau pengukuran dalam rencana kegiatan hariannya.

Pengertian hidup menurut pandangan masyarakat Bugis dalam pembahasan di atas diperoleh melalui wawancara mendalam dari seorang tokoh Masyarakat (bapak Muhammad Nur) yang dianggap berkompeten oleh salah satu kelompok masyarakat di kawasan Bugis Utara di salah satu kampung tua yang bernama Keera.

Berdasarkan MPL diperoleh keterangan bahwa SGSR sebagai pemimpin rerumpatan atau Dewi Padi menghendaki kedudukan yang terhormat, ditempatkan ditempat yang mulia, dan diperlakukan sesuai aturan tertentu yang manusiawi. Atas kedudukannya tersebut SGSR mendapat tempat khusus di rumah Bugis di bagian paling atas di bawah ruang atap yang disebut ruang rakkeang.

SGSR dalam bahasa ilmiah diperkirakan sebagai zat yang terkadung dalam bahan makan yang menjadi sumber hidup. Zat inilah yang menjadi sumber bahan makanan utama masyarakat Bugis. Manusia yang makan nasi menjadikan hidupnya berkualitas tinggi karena proses perolehan kandungan zat yang terdapat dalam sebutir nasi adalah sempurna, karena berasal dari gabungan unsur-unsur seluruh alam semesta. Padi sebelum menjadi nasi mengalami proses yang rumit dan panjang mengelilingi dunia. Perjalanan zat diperoleah dari unsur langit dan unsur bawah tanah.

Padi atau SGSR pertama tumbuh di atas pusara puteri hasil pernikahan penguasa langit dan penguasa bawah tanah/laut. Perjalanan hidupnya di bumi diantar oleh angin ribut, dibawa oleh petir, diarak oleh guntur gelagar, memegang pada kilat dan berpegangan pada guntur [6]. Keterangan perjalanan Dewi Padi sebagaimana diuraikan dapat dijelaskan tentang pengetahuan masyarakat Bugis pada jaman dahulu tentang kandungan unsur-unsur yang terdapat dalam biji padi. Padi menjadi makanan 
berkualitas karena air yang digunakan sebagai syarat tumbuhnya telah bersentuhan dengan kilat dan guntur di atas awan. Hasil pertemuan air dengan guntur dan kilat di awan memberikan zat yang dikirim ke bumi yang selanjutnya diserap ke dalam tanah untuk mengambil sumber kehidupan dari Dewa penguasa bawah tanah/laut yang akhirnya terserap dalam batang padi yang akhirnya menghasilkan biji padi yang menjadi sumber nutrisi (nasi) bagi manusia.

Seseorang yang telah hidup memerlukan kondisi idaman dalam kehidupannya berupa cita-cita atau dambaan pada tahapan dan tingkatan selanjutnya berupa kondisi batin yang aman dan damai. Keamanan dan kedamaian hidup ini diharapkan terjadi secara pribadi dan umum dalam lingkungan sosial dan masyarakat. Kondisi hidup seperti ini oleh masyarakat Bugis disebut maradeka. Dengan demikian hidup maradeka adalah dambaan hidup tertinggi bagi manusia Bugis. Manusia ketika sedang hidup sering sekali melupakan bahwa dia sedang hidup. Ingat hidup lebih banyak disadari ketika menghadapi peristiwa yang mendekati kematian.

\section{Pengertian Maradeka}

Kata maradeka dalam bahasa Bugis, besar kemungkinan mirip dengan kata merdeka dalam Bahasa Indonesia. Persamaan makna antara merdeka dan maradeka bukanlah penekanan dalam pembahasan ini tetapi perlu di kemukakan karena definisi merdeka belum sepenuhnya dipertegas di NKRI menurut pengertian kebangsaan hingga saat paper ini ditulis.

Maradeka dalam bahasa Bugis mengandung makna yang sangat dalam. Kajiannya akan menyadarkan manusia akan makna kehidupan damai yang sesungguhnya, baik secara pribadi maupun secara umum dalam lingkungan kehidupan sosial kemasyarakatan. Pengertian menurut sifat pribadi dapat dibagi menjadi 2 bagian yaitu secara pribadi sebagai individu dan kelompok secara sosial kemasyarakatan. Tatanan kehidupan maradeka dalam penataan pemerintahan juga terbagi 2 menurut sumbernya, sumber menurut lontaraq dan menurut keterangan budaya tutur.

Pengertian maradeka dalam lontaraq ATRW menjelaskan tentang tatanan hidup dan kehidupan secara pribadi, sosial dan tata pemerintahan. Penjelasan tatanan pemerintahan memuat hubungan pemerintah dan rakyat beserta hukum yang mengikatnya, berikut uraiannya.

Penjelasan kata maradeka secara umum tentang kondisi tatatan negeri dijelaskan bahwa negeri meradeka dapat dicapai bilamana dipertegas batasan dan peran masing-masing. Penegasan peran yang utama adalah penekanan kepada siapa yang disebut pemeritah dan kepada siapa yang berkedudukan sebagai rakyat. Rakyat dan pemerintah dalam negara maradaka harus saling mendukung dan berfikir untuk kebaikan negeri. Kebaikan sifat pemerintah dapat dilihat dan diukur dari kondisi kehidupan rakyatnya. Negeri yang memiliki rakyat yang makmur berarti personil yang duduk dalam pemerintahan berakhlak mulia, sebaliknya bila rakyat hidup sengsara dipastikan bahwa personil yang memegang jabatan dalam pemerintahan bersifat dan bertingkah laku buruk atau tidak terpuji. Kebaikan adalah kata yang digunakan dalam negeri maradeka, bukan menghendaki kemajuan sebagaimana tuntutan umum dijaman reformasi. Lontaraq menuliskan Mabbinruq nadeceng nрисарpaq artinya saling berfikir untuk mencari kebaikan. Bagi masyarakat Bugis mundur untuk menjadi lebih baik, lebih dihargai dari pada maju untuk hancur.

Prosedur pengangkatan pemimpin di negeri maradeka didasarkan atas kemuliaan sikap dan prilaku secara pribadi (sipaq mappabbatiq) sifat atau akhlak yang menjadi penentu. Seseorang yang berakhlak mulia dan memiliki keahlian tertentu untuk kemasylahatan ummat akan diusulkan menjadi pejabat pemerintah. Kondisi rekrutmen pemimpin di negeri maradeka berbeda dengan sistem kerajaan yang mengangkat pejabat berdasarkan keturunan atau menurut darah. Sejarah mencatat akan adanya kekosongan pemerintahan dalam negeri maradeka akibat tidak adanya sosok pribadi yang dapat diangkat menjadi pemimpin.

Pengertian maradeka menurut tatanan negara yang diperoleh melalui budaya tutur menjelaskan bahwa negeri maradeka adalah negeri yang diibaratkan sebagai kehidupan seorang petani. Padi disetarakan dengan rakyat dan petani disetarakan dengan pemerintah. Petani yang mengharapkan hasil pertanian yang baik akan memberikan kemampuan maksimalnya untuk melakukan pelayanan yang terbaik kepada padinya. Petani harus menjaga padinya dari gangguan hama dan penyakkit tanaman, memberikan pupuk yang baik untuk kesempurnaan hidupnya. 
Demikian perumpamaan negeri maradeka menurut tata pemerintahan. Setelah adanya penegasan tentang rakyat dan pemerintah maka tugas masing-masing menjadi jelas. Pemerintah harus melindungi rakyatnya, memberikan layanan yang terbaik agar dapat memperoleh hasil yang optimal.

Pengertian maradeka secara pribadi disebutkan dalam lontaraq sesuai cuplikan berikut: naiyya riasengnge maradeka tenrilawai ri eloqna taro pasoroq gauqna naita alena (Zainal Abidin), artinya: yang disebut maradeka adalah tak dihalangi keinginannya, selalu menjaga tingkah lakunya, mampu melihat dirinya. Redaksi kata dalam kalimat definisi maradeka di atas dapat dilihat bahwa laluhur Bugis membagi kebebasan manusia dalam tiga tingkatan. Tingkatan pertama adalah manusia memiliki dan memerlukan kebebasan yang besar sebebas bebasnya. Tingkatan kedua, manusia dalam kebebasannya dapat menerima pertimbangan dan menghentikan atau membatasi kebebasannya sesuai pertimbangan yang diberikan kepadanya. Tingkatan tertinggi adalah manusia memiliki sifat yang mampu melihat dirinya sebagai pengendali kebebasan.

Pengertian maradeka menurut tatanan sosial kemasyarakatan seusngguhnya sangat banyak salah satu diantaranya mangatakan maliu sipakaingeq maingeqpi napaja artinya lupa manusia yang sering lupa harus saling mengingatkan hingga sadar. Maknanya adalah kita harus saling membimbing dan mengarahkan untuk menjadi benar menurut akhlak mulia. Keterangan tersebut di atas digunakan untuk melihat penerapannya dalam penataan lingkungan bangunan rumah Bugis.

\section{Hidup Maradeka Dalam Tata Ruang Rumah Bugis}

Maradeka dalam keterangan lontaraq menjelaskan tingkatan kebebasan manusia yang terdiri dari 3 hierarki. Hierarki pertama adalah kebebasan besar, hierarki kedua kebebasan yang dapat dibatasi, dan hierarki ketiga adalah pengendali kebebasan. Makna maradeka tersebut diatas dalam penelitian sebelumnya mengungkapkan adanya kesesuaian antara ketegasan batasan ruang dengan fenomena kebebasan pergerakan manusia di rumah Bugis. Kebebasan Ruang bawah yang terdiri dari jejeran tiang memberi fasilitas untuk dapat bergerak sebebas bebasnya sebagai cerminan definisi maradeka utnuk tingkat kebebasan besar. Ruang tengah yang terbentuk dari jejeran tiang dan dibatasi bidang dinding dan lantai sebagai cerminan definisi maradeka untuk kebebasan manusia yang dapat dibatasi (Hartawan, Suhendro, Pradipto, Kusumawanto, 2015).

Dalam penelitian ini tatanan ruang dalam bangunan rumah Bugis tidak hanya sesuai dengan kebebasan dan batasan pergerakan manusia tetapi juga sesuai dengan jaminan hidup dan kehidupan. Jaminan hidup ini terungkap dalam keterangan MPL yang menjelaskan kedudukan SGSR yang ditempatkan di tempat terhormat di rumah Bugis. Tempat tinggal SGSR berada di ruang paling tinggi yaitu di rakkeang. Ruang tempat tinggal manusia di bagian tengah dan binatang di bawah kolong. Tananan ruang vertikal di rumah Bugis diperlihatkan dalam gambar berikut.

Gambar 1 memperlihatkan bentuk rumah Bugis dan potongannya menurut fungsi ruang secara vertikal. Ruang paling atas di bawah atap adalah ruang rakkeang berfungsi sebagai ruang penyimpanan bahan makan dalam hal ini padi. Ruang tengah adalah batabbola berfungsi sebagai ruang tempat tinggal manusia. Ruang paling bawah adalah kolong atau awa bola berfungsi sebagai tempat penyimpanan binatang ternak dan penunjang kehidupan lainnya. Penunjang kehidupan yang umum diletakkan di ruang ini adalah kayu bakar untuk memasak nasi; bahan makanan penunjang seperti kelapa, pisang, dan buah-buahan lainnya; bahan dan perlengkapan atau peralatan kerja. Dalam masyarakat Bugis dikenal istilah piring besar dan piring kecil. Piring besar berarti nasi sebagai bahan makan utama sementara piring kecil berarti makanan tambahan berupa lauk pauk dan makanan cemilan lainnya. Bahan untuk piring kecil diletakkan dibawah kolong.

Kondisi penataan ruang rumah Bugis secara vertikal sebagaimana diuraikan di atas menjelaskan bahwa manusia bilamana menghormati hidup dan kehidupannya, menghendaki kedamain, mereka harus memberi ruang untuk sumber kehidupan dan ruang untuk penunjang kehidupannya. Ketersediaan jaminan kehidupan dan penunjang kehidupan diyakini oleh masyarakat Bugis akan menjadi jaminan ketenteraman lahir dan batin. Tejaminnya hidup dan tenteramnya jiwa adalah hidup maradeka. 


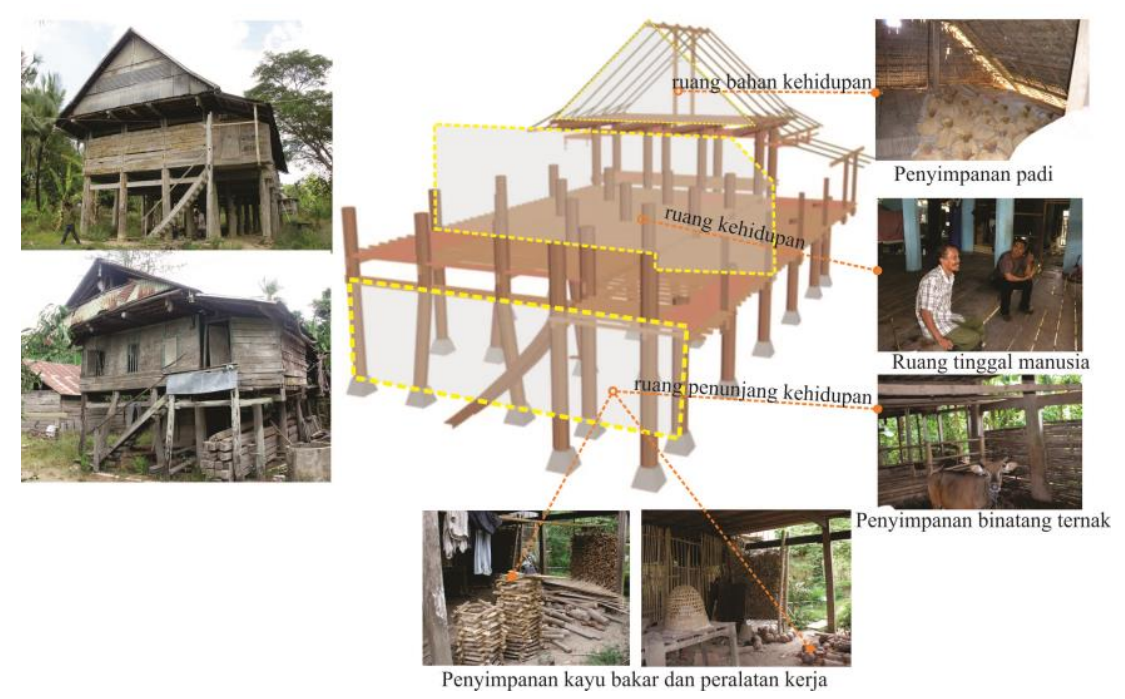

Gambar 1. Tatanan Ruang Vertikal Rumah Bugis

Tatanan ruang rumah Bugis seperti dijelaskan dapat dipahami akan pentingnya penyediaan sumber bahan makanan untuk kelangsungan hidup masyarakat di daerah Bugis. Bahaya kelaparan adalah hal yang sangat dihindari. Dalam lingkungan masyarakat Bugis lumrah terdengar ungkapan yang mengatakan "lebih baik mati berdarah daripada mati kelaparan". Demikian pentingnya peran ketersediaan dan penyiapan cadangan sumber bahan makan bagi masyarakat Bugis.

Manusia makan nasi dengan cara di masak menggunakan api atau bahan bakar lainnya. Pendamping makan nasi adalah sumber hayati dan nabati seperti lauk pauk dan sayur. Fenomena kebutuhan utama makanan manusia telah tersedia dalam ruang di rumah Bugis. Lauk pauk berupa binatang ternak dan cadangan buah telah tersedia. Kayu bakar untuk memasak nasi telah ada. Bahan untuk beras pun telah lengkap. Kondisi demikian menunjukkan jaminan kehidupan utama yang dapat dijangkau pengusahaan oleh tangan manusia untuk bertahan hidup. Rumah bugis adalah rumah yang menjamin hidup maradeka bagi penghinunya.

\section{Maradeka Dalam Tata Ruang Makro}

Tata ruang makro dalam lingkungan masyarakat Bugis dapat ditelusuri melalui kehidupan masyarakat Bugis Wajo (salah satu Kabupaten Bugis di Provinsi Sulawesi Selatan) pada masa awal terbentuknya permukimannya. Keterangan sejarah menjelaskan bahwa masyarakat saat itu hidup di sekitar lahan pertaniannya. Lahan yang ada disekitarnya digunakan sebagai tempat menggembalakan ternaknya. Orang yang disebut kaya pada saat itu adalah orang yang memiliki lahan pertanian dan binatang ternak yang digembalakan oleh anaknya sendiri. Gambaran tata ruang pada awal kehidupan masyarakat menurut ATRW (Gambar 2).

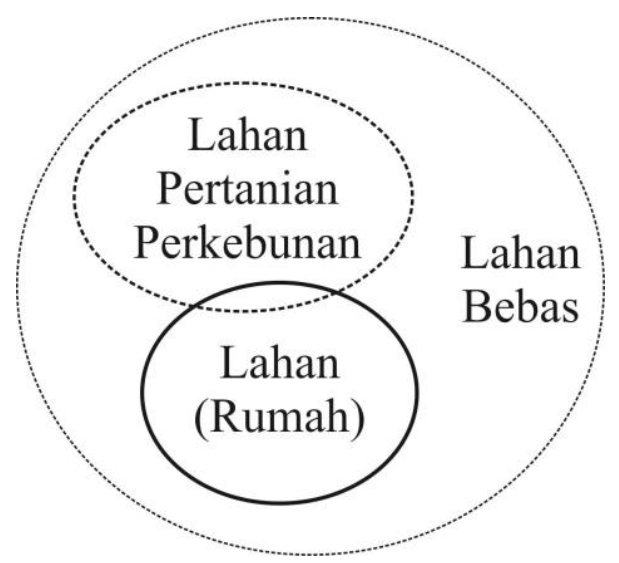

Gambar 2. Ruang Makro Permukiman Masyarakat Bugis

Kondisi tata ruang seperti dalam gambar di atas merupakan komposisi ruang yang menyulitkan pengendalian sosial kemasyarakatan dalam tatanan pemerintahan setelah kemerdekaan Indonesia. Hal ini terjadi karena tatanan ruang yang tercipta pada masa tersebut adalah kehidupan yang berjauhan dan menyebar dan mengakibatkan kesulitan dalam menjalankan roda pemerintahan. Kondisi inilah yang menjadi dasar lahirnya Keputusan Gubernur tentang pembentukan desa gaya baru. Akibat dari keputusan tersebut masyarakat yang 
tinggal tersebar disekitar lahan persawahannya dihimbau untuk tinggal penetap secara berkelompok dalam satu kelompok desa dan diawasi oleh pemerintah. Kondisi tata ruang sebagaimana dijelaskan pada awal terbentuknya permukiman di Wajo, imbasnya masih dapat dirasakan hingga awal tahun 1970an.

Berdasarkan pengalaman pribadi penulis pada tahun tersebut, suasana tatanan ruang yang sesuai dengan gambar di atas masih segar dalam ingatan. Lahan yang menjadi milik masyarakat hanyalah persawahan yang ditandai dengan pematang, lahan perkebunan yang ditandai dengan pagar, dan lahan tempat mendirikan rumah. Lahan selain dari yang disebutkan merupakan lahan bebas. Lahan ini digunakan untuk berbagai kebutuhan umum yang sifatnya untuk kepentingan bersama secara komunitas dan kehidupan binatang bebas lainnya. Fungsi lahan bebas tersebut seperti tempat untuk menggembala kerbau, tempat mengumpulkan kerbau ketika lahan pertanian telah ditanami, tempat beradu pacuan kuda, dan tempat binatang liar lainnya berkeliaran. Pada Masa ini kehidupan yang damai sangat terasa. Kehidupan yang menyediakan sumber hidup dan kehidupan yang melimpah adal warna lingkungan dijaman tersebut, tidak jarang manusia akan bertemu dengan binatang liar seperti rusa, kera, dan berbagai banatang liar lainnya ketika kita berjalan menuju ke sawah ketika keluar dari tidak jauh dari permukiman.

Kondisi ruang makro sebagaimana dijelaskan sesuai dengan tatanan hidup maradeka dalam ATRW. Ruang yang tersedia terbagi menjadi 3 bagian yaitu; ruang bebas, ruang perumahan, dan ruang pertanian.

Perkembangan selanjutnya sekitar awal tahun 1980an ketika masyarakat migran semakin bertambah banyak dan pembauran telah terjadi, mendesak kebutuhan ruang yang semakin tidak terkendali. Setiap jengkal ruang telah dikuasai oleh masyarakat yang nampaknya tanpa pertimbangan-pertimbangan untuk kebaikan lingkungan hidup secara berimbang dan berkesinambungan. Ruang kepentingan hunian lebih mendominasi, bahkan ruang untuk penunjang kehidupan dan ruang jaminan kehidupan kadang tanpa disadari menjadi tergusur.

Peningkatan tuntutan kebutuhan dan pemanfaatan ruang yang tidak terkendali dan tanpa pertimbangan perimbangan untuk tujuan kebaikan hidup manusia secara umum akan membawa efek negatif dan merupakan ancaman bagi kemanusiaan.

Akibat kebijakan pembentukan desa gaya baru, hubungan ruang menurut hierarki kebutuhan kehidupan telah bergeser dan semakin berjauhan. Perkembangan kebutuhan akibat lonjakan kebutuhan penduduk dan keragaman kebutuhan mengakibatkan hubungan ruang kebutuhan kehidupan semakin berjauhan. Kondisi ruang kehidupan yang berjauhan tersebut menjadikan suasana sosial ekonomi kemasyarakatan menjadi tergeser dan berimbas kepada kondisi hidup maradeka.

Secara umum manusia sangat ketakutan ketika dihadapkan dengan kondisi krisis ekonomi, mereka tidak menyadari bahwa krisis ekonomi tidak berarti apa-apa bila manusia menyadari betapa besarnya bahaya krisis makanan. Krisis makanan merupakan momok yang paling berbahaya dan sedapat mungkin dihindari. Menghindari bahaya besar ini memerlukan kesadaran penataan ruang makro yang berimbang secara kualitas dan kuantitas antara ruang tiga serangkai. Ruang penyedia sumber bahan makanan, ruang penunjang kehidupan, dan ruang hunian harus direncanakan dan dirancang sebaik mungkin.

Berdasarkan tata ruang mikro di bangunan rumah Bugis dan tata ruang makro dalam penataan ruang kehidupan yang didasari pertimbangan hidup maradeka yang telah memberikan kehidupan yang aman, tenteram, dan damai bagi masyarakatnya, maka seyogianya dapat diteruskan untuk menjadi pertimbangan dalam penataan ruang dijaman sekarang. Masyarakat Bugis primitif telah memberikan contoh penataan ruang yang manusiawi.

Pelajaran yang dapat diperoleh dari tatanan ruang hidup maradeka untuk digunakan sebagai dasar pertimbangan penataan ruang masa depan dapat dipetik 2 manfaat yaitu manfaat klasifikasi ruang dan manfaat hierarki pertimbangan penataan ruang. Manfaat klasifikasi fungsi ruang seharusnya dipertahankan untuk membagi kelompok fungsi ruang menjadi 3 bagian yaitu: ruang sumber kehidupan; ruang penunjang kehidupan; ruang hidup manusia. Manfaat hierarki pertimbangan penataan ruang seharusnya dibuat menjadi 3 yaitu pertimbangan yang bersumber dari ketetapan nasional sebagai pengikat NKRI; pertimbangan yang bersumber dari ketetapan regional sesuai potensinya; pertimbangan yang bersumber dari masyarakat menurut etnis. 
Pertimbangan penataan ruang yang terdiri dari 3 fungsi utama utama nampaknya sama dengan 3 tingkatan kebebasan manusia menurut definisi maradeka dari ATRW. Kebebasan besar analog dengan ruang bebas, kebebasan terbatas analog dengan ruang untuk rumah tinggal, dan pengendali kebebasan analog dengan ruang sumber bahan makanan. Pertimbangan mikro tercermin dalam tatanan kebebasan pribadi manusia dan rumah tinggalnya. pertimbangan makro seharusnya tercermin dalam penataan lingkungan dan ruang yang lebih besar.

Gambar 3 menjelaskan hubungan ideal antara ketiga ruang serangkai untuk kehidupan manusia yang hidup maradeka menurut pertimbangan pembangunan bagi masyarakat Bugis yang dapat digunakan untuk menata ruang makro.

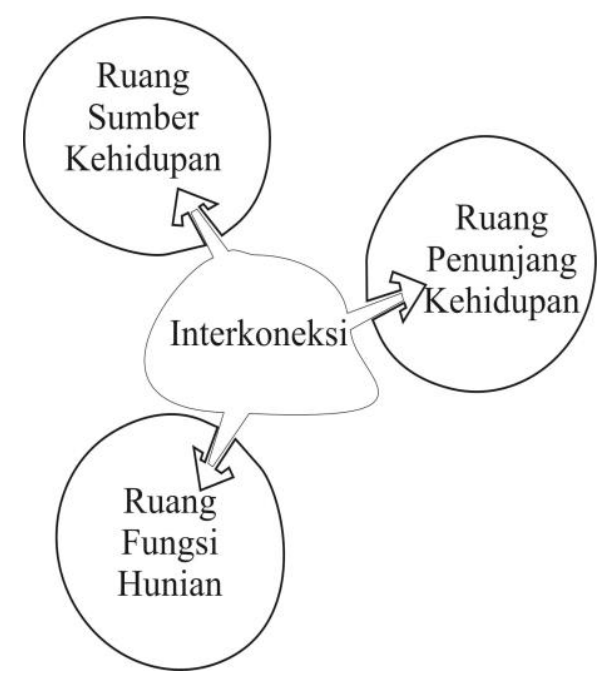

Gambar 3. Hubungan Ruang Makro

Fenomena hidup dan makan dalam kehidupan sehari-hari manusia terbukti dari banyak aktifitas yang menuntut pergerakan untuk makan. Ketika bangun pagi manusia bergerak memenuhi kebutuhan sarapan, siang hari bergerak memenuhi kebutuhan makan siang, menjelang malam bergerak memenuhi kebutuhan makan malan, dan diantara waktu tersebut banyak pergerakan yang dilakukan untuk memenuhi kebutuhan makan tambahan. Hubungan antara makan dan pergerakan sangat erat kaitannya sehingga hubungan antara keduanya menuntun kepada hakekat hidup dan kebebasan bergerak sebagaimana penjelasan hidup maradeka.

Berdasarkan keterangan dalam ATRW dan MPL tentang kehidupan masyarakat Bugis Wajo diawal terbentuknya permukiman negeri maradeka dapat ditarik beberapan bahan pelajaran untuk digunakan sebagai dasar pertimbangan dalam pentaan ruang mikro dan makro. Pertimbangan dan bahan pelajaran diuraikan berikut:

1. Pertimbangan perencanaan dan perancangan ruang mikro idealnya dilakukan dengan cara mempertimbangkan penggunaan ruang untuk 3 tingkatan kebebasan manusia. Terdapat ruang untuk bergerak bebas; terdapat ruang untuk kegiatan terbatas; dan terdapat ruang yang bersifat pribadi.

2. Pertimbangan penataan lingkungan makro idealnya direncanakan dan dirancang sebagaimana ruang mikro dengan skala yang lebih luas. Perkembangan dan pertumbuhan penduduk yang semakin meningkat seharusnya tetap mempersiapkan ruang untuk bahan makanan, ruang penunjang kehidupan, dan ruang kehidupan. Ketiga jenis ruang ini diupayakan secara proporsional dan terkoneksi oleh jaringan infra struktur yang terjamin kelancarannya.

3. Pertimbangan dalam hal kebijakan seyogianya dilakukan dengan membuat kebijakan penataan ruang dengan menggunakan 3 tingakatan. Tingkatan pertama merupakan kebijakan penataan ruang untuk kepentingan nasional. Tingkatan kedua merupakan kebijakan penataan ruang untuk kepentingan regional atau kawasan menurut potensi dan andalannya. Tingkatan ketiga merupakan kebijakan penataan ruang untuk kepentingan yang sesuai dengan keinginan yang bebas bagi penduduk suatu kawasan. Ketiga tingkatan kebijakan tersebut seharusnya dibuat saling terhubung menjadi satu kesatuan untuk kehidupan rakyat merdeka.

Dengan demikian perencanaan dan perancangan tata ruang untuk kehidupan manusia oleh masyarakat Bugis dapat digunakan sebagai dasar pertimbangan untuk kepentingan kehidupan kemanusiaan dengan fokus pertimbangan hidup maradeka. 


\section{KESIMPULAN}

Masyarakat Bugis menggunakan rumah panggung sejak jaman dahulu. Rumah jenis ini telah digunakan oleh masyarakat hingga paper ini ditulis dan bahkan masih digunakan hongga beberapa generasi kedepan. Eksistensi rumah seperti ini dapat bertahan lama karena perencaan dan perancangan tata ruang bangunan dan lingkungannya menggunakan pertimbangan yang sangat mendasar yaitu pertimbangan untuk hidup maradeka. Pertimbangan tersebut adalah refleksi 3 tingkatan kebebasan manusia. Kebebasan besar, kebebasan terbatas, dan pengendali kebebasan. Tiga tingkatan kebebasan tersebut dapat terlaksana untuk manusia yang hidup. Jaminan kehidupan ini ternyata telah tersedia dalam tata ruang vertikal rumah Bugis. Kehidupan maradeka sebagai dambaan manusia telah dijelaskan oleh leluhur Bugis dalam lontaraq MPL dan ATRW.

Pertimbangan penataan lingkungan mikro untuk penataan lingkungan makro idealnya disamakan tetapi dalam skala yang berbeda. Pertimbangan penataan ruang maradeka dari Bugis memberi pelajaran berharga untuk digunakan menata ruang masa depan di jaman modern ini.

Tatanan ruang yang harusnya direncanakan dan dirancang seimbang antara ruang sumber kehidupan, ruang penunjang kehidupan, dan ruang kehidupan seharusnya digunakan sebagai hak asasi ruang.

Pertimbangan penataan ruang yang dapat diperoleh dari pengetahuan masyarakat Bugis primitif tidak hanya terbatas dalam tata fisik melainkan menjangkau hingga konten kebijakan. Pertimbangan penataan ruang dalam hal ini dapat mempersatukan keragaman dalam negara besar dan beragam etnik seperti Indonesia.

\section{Daftar Pustaka}

Groat, L., and Wang, D. (2002) Architectural Research Method. John Wiley Son, Inc.

Hartawan., B. Suhendro., E. Pradipto., A. Kusumawanto. (2015) Relevansi Ruang Tiga Tingkatan Rumah Bugis dengan Kepercayaan dan Prinsip Hidup Masyarakat. The $5^{\text {th }}$ Annual Engineering Seminar, D87-D93.
Mattulada (1995) Latoa, Suatu Lukisan Analitis Terhadap Antropologi Politik Orang Bugis, Hasanuddin university Press.

Mardanas, I., Abu, R., Maria (1985) Arsitektur Tradisional Daerah Sulawesi Selatan. Proyek Inventarisasi dan Dokumentasi Kebudayaan Daerah Departemen Pendidikan dan Kebudayaan.

N. Rahman (2009) Kearifan Lingkungan Hidup Manusia Bugis, berdasarkan Meong Mpalo., Lagaligo Press., Makassar.

Pelras (2006) Manusia Bugis. Forum Jakarta Paris.

Tanpa Nama, Lontaraq Attoriolonge Ri Wajo. Transliterasi oleh Prof $\mathrm{H}$ A. Zainal Abidin. 